\title{
Lower serum chromogranin B level is associated with type 1 diabetes and with type 2 diabetes patients with intensive conservative insulin treatment
}

\author{
Zoltan Herold ${ }^{1 *} \mathbb{0}$, Magdolna Herold ${ }^{1}$, Klara Rosta $^{2}$, Marton Doleschall ${ }^{3 \dagger}$ and Aniko Somogyi ${ }^{1+}$
}

\begin{abstract}
Background: Chromogranin B (CgB) plays an important role in the physiological insulin secretion of pancreatic beta cells. Serum CgB levels were investigated in type 1 and type 2 diabetes patients in a cross-sectional study.

Methods: An observational cross-sectional study was performed with the inclusion of 94 control subjects, 100 type 1 and 100 type 2 diabetes patients, at the Metabolic Outpatient Clinic of the Department of Internal Medicine and Hematology, Semmelweis University. Serum CgB levels were measured with enzyme-linked immunosorbent assay.

Results: Serum CgB level was lower in type 1 diabetes patients than in matched control subjects $(p=0.0241)$, while they were equal in type 2 diabetes patients and controls $(p=0.1698)$. The subgroup of type 2 diabetes patients who received intensive conservative insulin treatment had significantly lower $\mathrm{CgB}$ levels compared to those with other regimens of antidiabetic therapies ( $p=0.0283$ ).
\end{abstract}

Conclusion: The lower serum CgB levels in the patients with type 1 diabetes and the type 2 diabetes patients with progressed disease stage suggested that the $\mathrm{CgB}$ production might be decreased due to the beta cell destruction and depletion.

Keywords: Chromogranin A, Chromogranin B, Diabetes mellitus Type 1, Diabetes mellitus Type 2

\section{Background}

Chromogranin A ( $\mathrm{CgA})$ and chromogranin B ( $\mathrm{CgB})$ are family members of the granin glycoproteins. Both proteins are expressed by neurons, endocrine and neuroendocrine cells throughout the body in different quantities [1]. Serum CgA is routinely used as a biomarker for neuroendocrine tumors [2]. Serum levels of $\mathrm{CgB}$ also rise in pancreatic neuroendocrine tumors, however, it is less commonly used as a diagnostic tool [3]. Measurement of

\footnotetext{
*Correspondence: herold.zoltan@med.semmelweis-univ.hu

${ }^{\dagger}$ Marton Doleschall and Aniko Somogyi share senior authorship

${ }^{1}$ Department of Internal Medicine and Hematology, Semmelweis

University, H-1088 Szentkiralyi u. 46, Budapest, Hungary

Full list of author information is available at the end of the article
}

$\mathrm{CgB}$ can be advantageous in patients with impaired renal function and/or undergoing antacid therapy, which both may result in false positive CgA concentrations [3, 4].

Chromogranins are associated with the carbohydrate metabolism: $\mathrm{CgA}$ is known to play a significant role in the development and pathogenesis [5-7] of type 1 diabetes and it is associated with some type 1 diabetes complications, which could develop into neuroendocrine tumors [8]. Animal and cellular models have shown that $\mathrm{CgB}$ is mostly related to the physiological insulin secretion [9-11], however, human clinical study investigating the connection between $\mathrm{CgB}$ and diabetes has not been conducted yet.

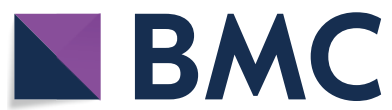

c The Author(s) 2020. This article is licensed under a Creative Commons Attribution 4.0 International License, which permits use, sharing, adaptation, distribution and reproduction in any medium or format, as long as you give appropriate credit to the original author(s) and the source, provide a link to the Creative Commons licence, and indicate if changes were made. The images or other third party material in this article are included in the article's Creative Commons licence, unless indicated otherwise in a credit line to the material. If material is not included in the article's Creative Commons licence and your intended use is not permitted by statutory regulation or exceeds the permitted use, you will need to obtain permission directly from the copyright holder. To view a copy of this licence, visit http://creativeco mmons.org/licenses/by/4.0/. The Creative Commons Public Domain Dedication waiver (http://creativecommons.org/publicdomain/ zero/1.0/) applies to the data made available in this article, unless otherwise stated in a credit line to the data. 


\section{Methods}

\section{Patients and study design}

An observational cross-sectional study was conducted. A total of 294 study subjects with Caucasian ancestry, who attended the Metabolic Outpatient Clinic of the Department of Internal Medicine and Hematology, Semmelweis University were enrolled in the study. Written informed consent was collected from all study subjects. The study was approved by the Regional and Institutional Committee of Science and Research Ethics, Semmelweis University. The study population consisted of 100 type 1 and 100 type 2 diabetes patients, and 94 control subjects. Exclusion criteria included known tumors, inflammatory bowel disease and systemic autoimmune diseases. At the time of diagnosis, classification of diabetes was based on C-peptide levels, islet-cell and/or glutamic acid decarboxylase antibody-positivity [12]. Intensive conservative insulin treatment (ICT) for type 2 diabetes patients was defined as a multicomponent regimen including basaland prandial insulins $[13,14]$.

\section{Clinical data and measurements}

Anamnestic data and body mass index (BMI) were collected; blood samples were drawn after an $8 \mathrm{~h}$ fasting period. Complete blood count, glycated hemoglobin $\left(\mathrm{HbA}_{1 \mathrm{C}}\right)$ and creatinine were measured at the Central Laboratory of Semmelweis University. Estimated glomerular filtration rate (eGFR) was calculated using the CKD-EPI equations [15]. Serum CgB levels were measured with the Human Chromogranin B (CHGB) enzyme-linked immunosorbent assay kit (dilution 10:1, abx151068, Abbexa Ltd., Cambridge, UK). Serum CgA levels were measured with the CGA-RIACT radioimmunoassay kit (CISbio International, Gif-sur-Yvette, France). As per manufacturer descriptions, both CgA and $\mathrm{CgB}$ kits detect larger protein sections, where no known cleavage products are located.

\section{Statistical analysis}

Statistical analyses were performed with $\mathrm{R}$ version 3.6.1 [16]. Welch two-sample t-tests, Fisher's exact tests, Spearman's rank correlation, regression models and propensity score matching ( $\mathrm{R}$ package Matching) was used. Results are expressed as mean \pm standard deviation; $p<0.05$ was considered as statistically significant.

\section{Results}

To test whether other factors such as age, sex, $\mathrm{HbA}_{1 \mathrm{C}}$, eGFR, BMI, the duration of diabetes, antacid therapy and/or known comorbidities affect serum CgB levels, univariate and multivariate regression models were used. None of these factors showed any effect on or association with CgB levels, neither within the individual study groups, nor in all of the patients. From the total of 94 control subjects, 62 and 47 age and sex matched subjects were selected via propensity score matching technique as the control population for type 1 and type 2 diabetes patients, respectively. Analysis on CgA was performed only on data where no CgA influencing factor was present $[3,4,7]$. Laboratory and anamnestic data of study subjects are summarized in Tables 1 and 2 .

Serum CgA level was significantly higher $(p=0.0348)$ in type 1 diabetes patients than that of healthy controls (Table 1), in accordance with our previous reports [8]. Type 1 diabetes patients had significantly lower serum CgB level $(p=0.0241)$ than the corresponding age- and sex matched control subjects (Fig. 1a). No correlation was found between serum CgA and CgB levels ( $p=0.7271)$.

Neither serum CgB levels ( $p=0.1698$; Fig. $1 b)$, nor CgA levels $(p=0.1587$; Table 2$)$ of all type 2 diabetes patients differed from those of their matched controls. The subgroup of type 2 diabetes patients with ICT $(n=34, \mathrm{CgB}$ : $84.87 \pm 40.37 \mathrm{ng} / \mathrm{mL}$ ) have significantly lower serum $\mathrm{CgB}$ levels $(p=0.0283$; Fig. 1c), compared to those patients, who are treated with any other regimens of antidiabetic therapies $(n=66, \mathrm{CgB}: 107.38 \pm 59.74 \mathrm{ng} / \mathrm{mL})$. No correlation could be verified between serum $\mathrm{CgA}$ and $\mathrm{CgB}$ levels $(p=0.7635)$.

\section{Discussion}

Serum CgA and CgB have higher levels in blood and correlate with each other in neuroendocrine tumors of various locations including foregut, midgut and adrenal medulla [2-4]. Interestingly, CgA and CgB levels did not correlate with each other and changed in different directions in type 1 diabetes mellitus. The serum CgA level increases with the progression of type 1 diabetes, and it is associated with the development of enterochromaffinlike cell hyperplasia and autoimmune gastritis [8], from which neuroendocrine tumors can arise $[17,18]$. In contrast, serum CgB level was lower in the patients with type 1 diabetes than those in healthy controls. We have demonstrated that neither CgA nor CgB level differed in type 2 diabetes patients from those in healthy controls, but serum CgB level was lower in the subgroup of type 2 diabetes patients with ICT.

$\mathrm{CgB}$ derives from numerous neurons, endocrine and neuroendocrine cell types throughout the human body [1]. CgB contributes to the physiological secretion of insulin in pancreatic beta cells [9-11], moreover, it may take part in the signal transduction of insulin secretion [19]. Furthermore, the messenger RNA quantity of $\mathrm{CgB}$ is reduced in pancreatic islets of type 2 diabetes patients than that of non-diabetic control subjects [20]. CgB was significantly lower with $17 \%$ in type 1 diabetes patients and with $21 \%$ in type 2 
Table 1 Anamnestic and laboratory measurement data of type 1 diabetes patients

\begin{tabular}{|c|c|c|c|}
\hline Variable & Type 1 diabetes patients $[n=100]$ & Age and sex matched controls [ $n=62]$ & $p$ value \\
\hline Age [years] & $42.2 \pm 13.4$ & $44.1 \pm 16.8$ & 0.4443 \\
\hline Duration of diabetes [years] & $17.3 \pm 10.1$ & - & - \\
\hline Chromogranin A [ng/mL] ${ }^{a}$ & $61.64 \pm 55.27$ & $48.03 \pm 19.99$ & 0.0348 \\
\hline Chromogranin B [ng/mL] & $89.39 \pm 34.23$ & $107.38 \pm 59.77$ & 0.0241 \\
\hline $\mathrm{HbA}_{1 \mathrm{C}}[\%]$ & $8.0 \pm 1.7$ & - & - \\
\hline $\mathrm{HbA}_{1 \mathrm{C}}[\mathrm{mmol} / \mathrm{mol}]$ & $64.0 \pm 18.6$ & - & - \\
\hline White blood cell count $\left[10^{9} / \mathrm{L}\right]$ & $6.91 \pm 1.77$ & $7.08 \pm 1.95$ & 0.5894 \\
\hline Red blood cell count $\left[10^{12} / \mathrm{L}\right]$ & $4.88 \pm 0.51$ & $5.04 \pm 0.56$ & 0.0739 \\
\hline $\mathrm{eGFR}\left[\mathrm{mLmin}{ }^{-1}\left(1.73 \mathrm{~m}^{2}\right)^{-1}\right]$ & $100.79 \pm 18.65$ & $100.26 \pm 16.10$ & 0.8483 \\
\hline Body mass index (BMI) $\left[\mathrm{kg} / \mathrm{m}^{2}\right]$ & $25.6 \pm 5.0$ & $25.9 \pm 5.3$ & 0.7505 \\
\hline Sex (Female / Male) & 50: 50 & $31: 31$ & 1.0000 \\
\hline Hypertension & 47 & 17 & 0.0140 \\
\hline Thyroid disease & 31 & 4 & 0.0002 \\
\hline Gastroesophageal reflux disease & 14 & 7 & 0.8104 \\
\hline Antacid therapy & 6 & 5 & 0.7499 \\
\hline
\end{tabular}

Values are expressed as mean \pm standard deviation, unit of anamnestic data is the number of observations eGFR Estimated glomerular filtration rate, $\mathrm{HbA}_{1 C}$ Glycated hemoglobin

a Excluding the measurement of study subjects, who had any condition leading to chromogranin A elevation $[3,4,7]$. Remaining number of observations was 91 and 56 , respectively

Table 2 Anamnestic and laboratory measurement data of type 2 diabetes patients

\begin{tabular}{|c|c|c|c|}
\hline Variable & Type 2 diabetes patients [ $n=100]$ & Age and sex matched controls [ $n=47]$ & $p$ value \\
\hline Age [years] & $63.0 \pm 11.6$ & $58.4 \pm 14.6$ & 0.0589 \\
\hline Duration of diabetes [years] & $13.7 \pm 10.3$ & - & - \\
\hline Chromogranin A $[\mathrm{ng} / \mathrm{mL}]^{\mathrm{a}}$ & $57.80 \pm 34.74$ & $49.97 \pm 22.29$ & 0.1587 \\
\hline Chromogranin B [ng/mL] & $99.72 \pm 54.79$ & $112.54 \pm 61.68$ & 0.1698 \\
\hline $\mathrm{HbA}_{1 \mathrm{C}}[\%]$ & $7.3 \pm 1.2$ & - & - \\
\hline $\mathrm{HbA}_{1 \mathrm{c}}[\mathrm{mmol} / \mathrm{mol}]$ & $56.0 \pm 13.1$ & - & - \\
\hline White blood cell count $\left[10^{9} / \mathrm{L}\right]$ & $7.93 \pm 2.08$ & $7.21 \pm 1.91$ & 0.0443 \\
\hline Red blood cell count $\left[10^{12} / \mathrm{L}\right]$ & $4.82 \pm 0.39$ & $5.01 \pm 0.56$ & 0.0389 \\
\hline $\mathrm{eGFR}\left[\mathrm{mLmin} \min ^{-1}\left(1.73 \mathrm{~m}^{2}\right)^{-1}\right]$ & $83.49 \pm 17.84$ & $90.19 \pm 13.13$ & 0.0117 \\
\hline Body mass index (BMI) $\left[\mathrm{kg} / \mathrm{m}^{2}\right]$ & $31.1 \pm 5.8$ & $27.9 \pm 5.4$ & 0.0017 \\
\hline Sex (Female / Male) & 50: 50 & $24: 23$ & 1.0000 \\
\hline Hypertension & 91 & 17 & $<0.0001$ \\
\hline Thyroid disease & 16 & 4 & 0.3038 \\
\hline Gastroesophageal reflux disease & 31 & 5 & 0.0074 \\
\hline Antacid therapy & 29 & 3 & 0.0013 \\
\hline
\end{tabular}

Values are expressed as mean \pm standard deviation, unit of anamnestic data is the number of observations

eGFR Estimated glomerular filtration rate, $\mathrm{HbA}_{1 C}$ Glycated hemoglobin

a Excluding the measurement of study subjects, who had any condition leading to chromogranin A elevation $[3,4,7]$. Remaining number of observations was 64 and 43 , respectively

diabetes patients with ICT compared to the matched groups in the current study. Both type 1 diabetes patients and type 2 diabetes patient with ICT featuring progressed disease state have got pancreatic beta cell damage to different extent [21,22]; and the need for ICT is an indirect indication of beta cell damage [23]. Therefore, the reduced $\mathrm{CgB}$ production due to beta cell damage may cause the observed lower serum $\mathrm{CgB}$ levels in diabetes. 

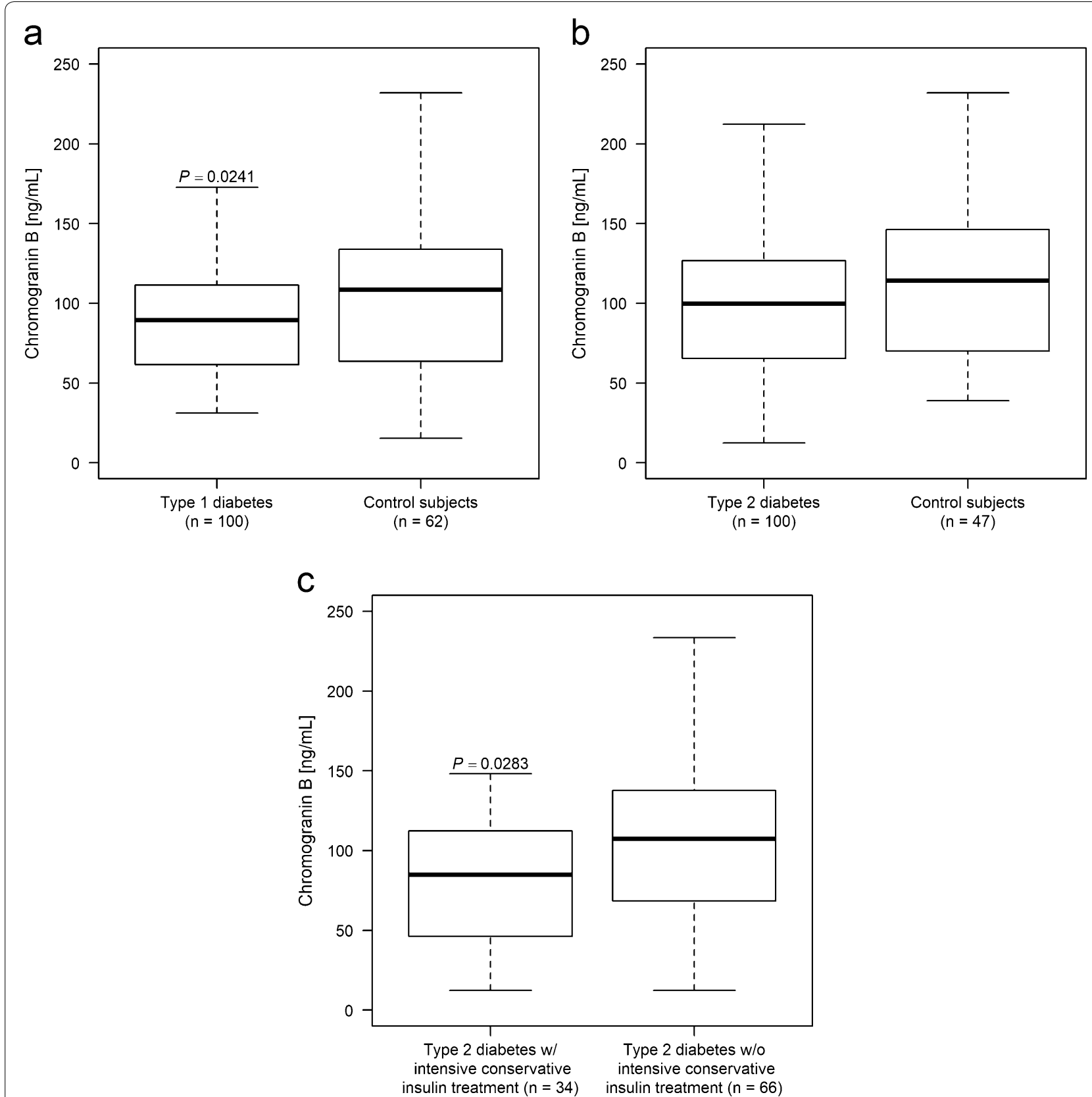

Fig. 1 Serum chromogranin B (CgB) level of study subjects. In type 1 diabetes patients serum CgB levels were significantly lower than those in sex- and age-matched controls (a), whereas in type 2 diabetes (b) the 2 cohorts did not differ. Subgroup analysis depending on the type of therapy in type 2 diabetes $(\mathbf{c})$ revealed that patients on intensive conservative insulin treatment had significantly lower serum CgB levels, compared to other regimens of therapy

\section{Conclusions}

In summary, the autoimmune destruction of beta cells might be the cause behind the lower serum CgB level in type 1 diabetes, and lower $\mathrm{CgB}$ were observed in type 2 diabetes with progressed disease state, which is also characterized by beta cell damage, however, this assumed cause is hardly proven in humans. Limitations of the current study are the relatively smaller sample size and the lack of serum C-peptide measurements. To support the assumed causative relationship between $\mathrm{CgB}$ and diabetes, further functional investigations are needed in model systems. 


\section{Abbreviations}

BMI: Body mass index; CgA: Chromogranin A; CgB: Chromogranin B; eGFR: Estimated glomerular filtration rate; $\mathrm{HbA}_{1}$ : Glycated hemoglobin; ICT: Intensive conservative insulin treatment.

\section{Acknowledgements}

Not applicable

\section{Authors' contributions}

Conception and study design: Z.H. and A.S. Acquisition, analysis and interpretation of data: Z.H., M.H., M.D. Drafting the work: Z.H., M.D, M.H. All authors read and approved the final manuscript.

\section{Funding}

ZH was supported by Wörwag Pharma Kft (Wörwag Research Prize for PhD students). MD was supported by the Hungarian Academy of Sciences (Janos Bolyai Research Scholarship) and the Ministry for Innovation and Technology (UNKP-19-4 New National Excellence Program). Research was supported by the National Research, Development and Innovation Office (grant number K-116128) and by the Hungarian Diabetes Association.

\section{Availability of data and materials}

The datasets used and/or analysed during the current study are available from the corresponding author on reasonable request.

\section{Ethics approval and consent to participate}

Study was approved by the Regional and Institutional Committee of Science and Research Ethics, Semmelweis University (approval ID: 21-13/1994, date of last modification and approval of modifications: 15-JAN-2019).

\section{Consent for publication}

Not applicable.

\section{Competing interests}

The authors declare that they have no competing interests.

\section{Author details}

${ }^{1}$ Department of Internal Medicine and Hematology, Semmelweis University, $\mathrm{H}-1088$ Szentkiralyi u. 46, Budapest, Hungary. ${ }^{2}$ Department of Obstetrics and Gynecology, Medical University of Vienna, Vienna, Austria. ${ }^{3}$ Molecular Medicine Research Group, Eotvos Lorand Research Network and Semmelweis University, Budapest, Hungary.

Received: 12 May 2020 Accepted: 4 July 2020

Published online: 14 July 2020

\section{References}

1. Winkler $\mathrm{H}$, Fischer-Colbrie R. The chromogranins A and B: the first 25 years and future perspectives. Neuroscience. 1992;49:497-528.

2. Stridsberg M, Husebye ES. Chromogranin A and chromogranin B are sensitive circulating markers for phaeochromocytoma. Eur J Endocrinol. 1997;136:67-73.

3. Miki M, Ito T, Hijioka M, Lee L, Yasunaga K, Ueda K, Fujiyama T, Tachibana Y, Kawabe K, Jensen RT, Ogawa Y. Utility of chromogranin B compared with chromogranin A as a biomarker in Japanese patients with pancreatic neuroendocrine tumors. Jpn J Clin Oncol. 2017:47:520-8.

4. Stridsberg M, Eriksson B, Fellstrom B, Kristiansson G, Tiensuu JE. Measurements of chromogranin B can serve as a complement to chromogranin A. Regul Pept. 2007;139:80-3.

5. Stadinski BD, Delong T, Reisdorph N, Reisdorph R, Powell RL, Armstrong M, Piganelli JD, Barbour G, Bradley B, Crawford F, Marrack P, Mahata SK, Kappler JW, Haskins K. Chromogranin A is an autoantigen in type 1 diabetes. Nat Immunol. 2010;11:225-31.

6. Li Y, Zhou L, Li Y, Zhang J, Guo B, Meng G, Chen X, Zheng Q, Zhang L, Zhang M, Wang L. Identification of autoreactive CD8+T cell responses targeting chromogranin A in humanized NOD mice and type 1 diabetes patients. Clin Immunol. 2015;159:63-71.

7. Herold Z, Doleschall M, Kovesdi A, Patocs A, Somogyi A. Chromogranin $A$ and its role in the pathogenesis of diabetes mellitus. Endokrynol Pol. 2018:69:598-610.

8. Herold Z, Herold M, Nagy P, Patocs A, Doleschall M, Somogyi A. Serum chromogranin A level continuously rises with the progression of type 1 diabetes, and indicates the presence of both enterochromaffin-like cell hyperplasia and autoimmune gastritis. J Diabetes Investig. 2020. https:// doi.org/10.1111/jdi.13203.

9. Bearrows SC, Bauchle CJ, Becker M, Haldeman JM, Swaminathan S, Stephens SB. Chromogranin B regulates early-stage insulin granule trafficking from the Golgi in pancreatic islet beta-cells. J Cell Sci. 2019;132:pii:jcs231373.

10. Boonen K, Baggerman G, D'Hertog W, Husson SJ, Overbergh L, Mathieu C, Schoofs L. Neuropeptides of the islets of Langerhans: a peptidomics study. Gen Comp Endocrinol. 2007;152:231-41.

11. Obermuller S, Calegari F, King A, Lindqvist A, Lundquist I, Salehi A, Francolini M, Rosa P, Rorsman P, Huttner WB, Barg S. Defective secretion of islet hormones in chromogranin-B deficient mice. PLoS ONE. 2010;5:e8936.

12. Decochez K, Tits J, Coolens JL, Van Gaal L, Krzentowski G, Winnock F, Anckaert E, Weets I, Pipeleers DG, Gorus FK. High frequency of persisting or increasing islet-specific autoantibody levels after diagnosis of type 1 diabetes presenting before 40 years of age. The Belgian Diabetes Registry. Diabetes Care. 2000;23:838-44.

13. Gaál Zs, Gerő L, Hidvégi T, Jermendy Gy, Kempler P, Winkler G, Wittmann I. Healthcare professional guidelines-diagnosis of diabetes mellitus, antihyperglycemic treatment and care of diabetics in adulthood. Diabetologia Hungarica. 2017;25:3-77.

14. American Diabetes Association. 9. Pharmacologic approaches to glycemic treatment: standards of medical care in diabetes-2020. Diabetes Care. 2020;43(Suppl 1):98-110.

15. Schwandt A, Denkinger M, Fasching P, Pfeifer M, Wagner C, Weiland J, Zeyfang A, Holl RW. Comparison of MDRD, CKD-EPI, and Cockcroft-Gault equation in relation to measured glomerular filtration rate among a large cohort with diabetes. J Diabetes Complications. 2017;31:1376-83.

16. R Core Team. R: a language and environment for statistical computing. Vienna: R Foundation for Statistical Computing. 2019. https://www.r-proje ct.org. Accessed 1 Aug 2019.

17. Bizzaro N, Antico A, Villalta D. Autoimmunity and gastric cancer. Int J Mol Sci. 2018;19:377-90.

18. Gluckman CR, Metz DC. Gastric neuroendocrine tumors (carcinoids). Curr Gastroenterol Rep. 2019;21:13-20.

19. Yadav GP, Zheng H, Yang Q, Douma LG, Bloom LB, Jiang QX. Secretory granule protein chromogranin B (CHGB) forms an anion channel in membranes. Life Sci Alliance. 2018:1:e201800139.

20. Bugliani M, Liechti R, Cheon H, Suleiman M, Marselli L, Kirkpatrick C, Filipponi F, Boggi U, Xenarios I, Syed F, Ladriere L, Wollheim C, Lee MS, Marchetti P. Microarray analysis of isolated human islet transcriptome in type 2 diabetes and the role of the ubiquitin-proteasome system in pancreatic beta cell dysfunction. Mol Cell Endocrinol. 2013;367:1-10.

21. Katsarou A, Gudbjornsdottir S, Rawshani A, Dabelea D, Bonifacio E, Anderson BJ, Jacobsen LM, Schatz DA, Lernmark A. Type 1 diabetes mellitus. Nat Rev Dis Primers. 2017;3:17016.

22. DeFronzo RA, Ferrannini E, Groop L, Henry RR, Herman WH, Holst JJ, Hu FB, Kahn CR, Raz I, Shulman Gl, Simonson DC, Testa MA, Weiss R. Type 2 diabetes mellitus. Nat Rev Dis Primers. 2015;1:15019.

23. Swinnen SG, Hoekstra JB, DeVries JH. Insulin therapy for type 2 diabetes. Diabetes Care. 2009;32(Suppl 2):253-9.

\section{Publisher's Note}

Springer Nature remains neutral with regard to jurisdictional claims in published maps and institutional affiliations. 